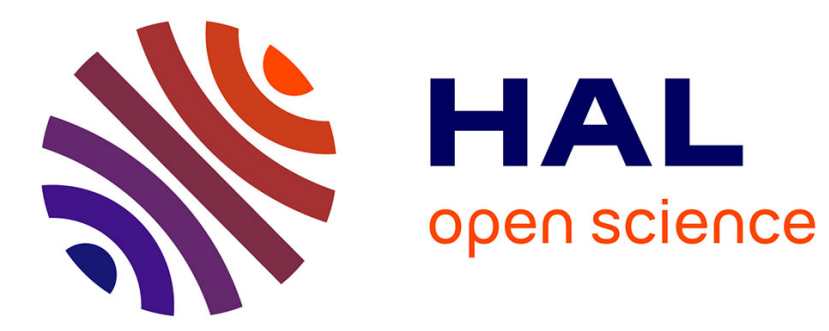

\title{
On the survival of butterflies in the jungle of urban systems
}

\author{
Lena Sanders, Isabelle Thomas, Céline Vacchiani-Marcuzzo
}

\section{To cite this version:}

Lena Sanders, Isabelle Thomas, Céline Vacchiani-Marcuzzo. On the survival of butterflies in the jungle of urban systems. Pumain D. Theories and Models in Urbanization, Springer International Publishing, 2020, 978-3-030-36655-1. 10.1007/978-3-030-36656-8_9 . halshs-02962688

\section{HAL Id: halshs-02962688 https://shs.hal.science/halshs-02962688}

Submitted on 9 Oct 2020

HAL is a multi-disciplinary open access archive for the deposit and dissemination of scientific research documents, whether they are published or not. The documents may come from teaching and research institutions in France or abroad, or from public or private research centers.
L'archive ouverte pluridisciplinaire HAL, est destinée au dépôt et à la diffusion de documents scientifiques de niveau recherche, publiés ou non, émanant des établissements d'enseignement et de recherche français ou étrangers, des laboratoires publics ou privés. 
Partie « 1 Economy versus geography: theories of urbanization and cities development" On the survival of butterflies in the jungle of urban systems

\author{
Lena SANDERS, Isabelle ThOMAS, Céline VACCHIANI-MARCUZZO
}

\title{
1- Introduction
}

In 2005 Gilles Duranton and Andrés Rodriguez-Pose signed a paper entitled "When economists and geographers collide, or the tale of the lions and the butterflies ". Let's briefly recall the demonstration of the two authors, one being a geographical economist, the other an economic geographer. Through analyses of cross citations and behaviors at conferences, they conclude to a relation of "mutual ignorance, rather than outright discord" between the researchers of these two communities. Looking at their scientific approaches, they underline two radically different ways of proceeding: the lions "improving and expanding their tricks", laboring "the same core questions over and over again", and the butterflies "freely flying the fields of knowledge with the aim of tasting the best from every flower they visit". The two authors note that both communities are in fact interested in the same questions (among others, the geography of cities), but that there is very little scientific cross-fertilization

At the same period (2007), a similar debate took place in the French scientific journal L'Espace Géographique: Denise Pumain, Jacques-François Thisse, Isabelle Thomas and Bernard Walliser tried to explore the relationship between New Economic Geography and Geography. Jacques-François Thisse conceded at this occasion that "En ce qui concerne les échelles spatiales, il est exact que la plupart des économistes n'ont pas compris grand-chose à cette question ${ }^{1} »$.

One specific point in this debate deserves to be focused on, that of spatial scales, that is maybe a major point of discrepancy between lions and butterflies. Indeed, initially (and very broadly said), economists (the lions) were myopic, considering a city as a point on a line (1D), and hence over simplifying urban realities for the sake of rigorous economic theory. At the same time, geographers (the butterflies), more aware of the crucial role of scale, were

\footnotetext{
${ }^{1}$ As far as spatial scales are concerned, it is true that most economists have not understood much about this question.
} 
analyzing multiple urban spatial dimensions (2D and more) gathering nectar from different theoretical and empirical fields. Even if both were dealing with urban matters, they were busy with different aspects.

What is the situation today, a bit more than a decade after these early debates? Steinberg (2015) recently compared publications and citations of German-speaking economic geographers and geographical economists. He observed more cross-fertilizations than expected, especially because young scholars are doing much better. Things are then improving even if joint publications remain rare and geographers are still seldom cited by economists (while the opposite is less true: geographers cite economists). The same holds for non-German researchers. If in the past 20 years, few economists and geographers have successfully worked together and shared some topics, such experiences remain unfortunately to be pinpointed and gaps between both disciplines persist with the advantage of a strong and well recognized (economic) theory for the firsts, and a good knowledge of space, its biases and the inherent quantitative methods for the others. As a consequence, economists have long looked at empirical analyses with contempt. Surely, if these two disciplines could more often listen to each other, research objectives would be for sure more challenging and results scientifically more exciting. It is important to insist on that as nowadays, the empirical context has changed. With the emergence of massive geolocalised data, new actors have appeared, coming from a variety of other disciplines than economy and geography (physicists, engineers, computer and data scientists), bringing new methods to analyze the structure of urban space. They are new predators in the jungle. Is it time for a new tale? Or time for the butterflies to be listened to by lions and these new panthers!

This metaphor was adopted at the ERC colloquium to discuss Michael Storper's contribution entitled "Urban systems: the geography of income and population". Michael Storper is, indeed, an example of the a priori impossible hybridity between lions and butterflies. His position at the interface of the economic and geographic worlds is extremely fruitful for studying cities' dynamics and makes him a particularly interesting researcher to discuss with. Referring to the question of why urban systems exist and why cities' sizes are organized in a hierarchical way, Storper discussed in his presentation previous models (Simon 1955, Ga baix 
1999, Henderson 1974) and argued for a better account of income in urban models. In the discussion that followed our own presentation, Storper underlined his position as a methodologic individualist, the only tenable position in social sciences according to him and he criticized geographers for not having a theory on individuals' spatial behavior. According to him, human agents have to be considered in an approach going from micro to macro level, otherwise there are just "statistical agents".

Our aim is here twofold. On the one hand, we want to discuss this position of the lions rooted in methodological individualism and in particular the "necessity" to adopt such an approach in order to understand the dynamics of a system of cities. Indeed this seems to be the mainstream position in economy when butterflies' explore different ways of flying from one scale to another. On the other hand, we will focus on the question of delineation of spatial objects like cities. The discussion is based on three complementary points. First we build on philosophers' tools in order to explore more deeply the meaning of methodological individualism when modelling cities' dynamics (Section 2). Then we build on an empirical approach to discuss how proper scale choice associated to a multiscale approach favors comparison (Section 3). At last, we expose the feedback of an interdisciplinary experience where the city delineation played a crucial role when developing a LUTI model (Section 4). We admit that the facts are sometimes a bit exaggerated; it is in order to underline them and to open the debate. Indeed, we are convinced that more opening and interactions between butterflies, lions and tigers, will help the ecosystem to be more resilient.

\section{2- How can philosophers help butterflies? An ontological perspective}

For urban economics the challenge is to provide micro-foundations to the existence and dynamics of urban systems. In particular, the regular rank-size distribution of cities remains a mystery in the sense that no satisfactory model based on individuals' behavior, i.e. based on a methodological individualism approach, has yet been developed (Krugman, 1996). There is a large literature in that field and we agree with Storper's point: "it is a distraction to focus on whether a pure Zipf exists or not"; "we should be interested in urban systems, but not overly concerned with a $q=1$ Zipf" (Storper, 2017). But, does a theory of systems of cities necessarily imply developing a theory of individuals' behavior (perceptions, intentions, 
preferences, actions) in the inter-urban space? That is the question we raise, building on an ontological approach. Our aim is here to discuss this position and defend the idea that it is not necessary, neither the most adequate, to formalize hypotheses at the microlevel of individual agents to explain the hierarchical structure and dynamics of a system of cities. We question whether explanatory mechanisms can be modelled at the city level without considering cities as "statistical agents". To this end we first discuss ontological issues about cities: what is their ontological status, in what sense can cities be considered as autonomous collective entities making sense? We then scrutinize their explanatory potential by briefly comparing two families of simulation models, microsimulation based on methodological individualism principles and a multi-agent system based on autonomous "city-agents".

Let's start with two quotations to illustrate the variety of positions according to methodological individualism (MI):

- "For many economists, a denial of methodological individualism simply signals that a person is confused and does not truly understand economics. In contrast, for many sociologists, supporting methodological individualism signals an anti-sociological reductionist attitude that is bound to overlook many crucial aspects of social reality." (Ylikoski, 2014)

- "Political science is divided between those who think that a scientific approach to the study of politics requires methodological individualism and those who consider this idea hopelessly reductionistic."..... List and Spiekermann (2013)

Of course it is a bit of a caricature to start the discussion with these two quotes but they have the merit to highlight the extreme variety of points of view on methodological individualism and to show that the debate goes far beyond a discussion between geographers and economists. Evolving in the mainstream of economy, lions are clearly on the methodological individualism (MI) side when, quite naturally in the butterflies' scientific world, both positions co-exist in the same way as mentioned by List and Spiekermann (2013) for the field of political science. Debates are old and dense, as well in philosophy as in social science but these authors underline that: "A reconciliation becomes possible once we see that there is not just one version of each view, but many, and that being an individualist in some respects is compatible with being a holist in others." 
Indeed perspectives have evolved in time and much more balanced positions than the simple opposition holism/individualism have emerged. Lars Udehn (2014) for example underlines that he is much less negative to methodological individualism than he was in earlier work (Udehn 2001) due to the spread of weaker definitions of MI. In sociology, Keith Sawyer (2002) defends a "nonreductive individualism" by distinguishing ontological individualism (1) and methodological individualism (2). In the former case, individuals are the only "things" to exist and "sociological objects and properties are nothing, but combinations of individuals and their properties ». Examples of such social objects could be as diverse as a football team, a company's board of directors, a state. Case (2) states that each phenomenon observed at a collective level can be explained by individuals' behavior. A "nonreductive individualism" consists in claiming (1) but not (2) (Sawyer 2002). That means that even if solely individuals exist as social objects from an ontological point of view, social laws are not reducible to individual laws (in terms of intentions, aims, perceptions) and collective entities can be used in an explanatory perspective. In the field of political science List and Spiekermann (2013) formulate that kind of question in following terms: "A key point of contention is the status of collective entities such as states, nations, ethnic groups, cultures, political parties, and other institutions. Are these mere by-products of individual behavior, or are they of independent ontological and/or causal significance?"

In order to move forward in the discussion, let us examine Sawyer's propositions (1) and (2) in the case of cities. From an ontological perspective, point (1) of Sawyer goes back to discuss if cities are to be considered as simple aggregates of people and firms or as autonomous entities. Reflecting upon the existence of the state and on its ontological status, Hay (2014) underlines that: "the state is an abstraction - a conceptual or theoretical construct-.... Its existence is not obvious nor evident, it has no physical or material presence, it is not visible, it is not directly accessible to any of the senses. ".

On the one hand, unlike the concept of state, that of city corresponds to a referent with a physical dimension, a materiality which is visible for everyone and which persists in time. It is clearly identifiable in the landscape and in that sense it corresponds, in a way, to a " bona fide » object (objects of common sense) as defined by Smith and Varzi (2000). On the other hand, an aggregate of buildings, pavements, and transport infrastructures is insufficient to 
define a city and to distinguish it from ontologically different objects as villages or towns. In addition, a city cannot be delineated in the same way as an individual, an island or a lake. In that sense, a city's boundaries correspond clearly, in Smith and Varzi's categorization, to a « fiat " object (constructed object according to an administrative, social or political convention). Thus, cities are constructed entities, in particular their delineation, but they are not pure abstractions, in contrast to social entities as states or political parties, as they have a material referent. One could then defend, and it is our position, that the city is an autonomous entity whose properties are not solely derived from statistical aggregates of individuals and firms. Indeed, a collection of individuals and enterprises are not enough to make a city and an aggregation of individuals' behaviors is not sufficient to understand why a city is expanding or declining, even if one takes into account the relations between these individuals. Nevertheless, from an ontological perspective, it is clear that cities are not "bona fide" objects as are individuals. The discussion points then to the city as a relevant "bona fide" ontological object in the sense that a material referent of common sense exists and a "fiat" object in the sense that its recognition and delineation are based on an abstract mode of construction. From an ontological point of view, the status of the city is then intermediate between "bona fide" objects as individuals, buildings, lakes, and "fiat" objects as households or states.

To carry on the discussion by examining Sawyer's proposition (2) concerning explanation, we can start with Hay's statement regarding the state:

It is "certainly possible to see the state as a conceptual or theoretical abstraction that lacks a direct real world referent whilst still according it an explanatory power or analytical purchase (as a theoretical construct)" (Hay, 2014).

Let's suppose that our project is to explain a city's dynamics within a system of cities. Different candidates to explanation can then be discussed, based on following questions: can such phenomena be explained only relating to individuals' actions or should mechanisms of change be looked for at the level of the cities as autonomous entities? In other terms, should explanation be developed at the level of the individuals living in the city or at a higher scale? Would it be sufficient only to focus on individuals' behavior when getting a job, choosing a place of living or a place to shop? What is the role of the decisions of macro-actors as 
entrepreneurs, planners, politicians? Does it make sense to formalize hypotheses on the behavior of entities of higher level as cities? The model developed will depend on the researcher's position on these issues.

Microsimulation models for example refer clearly to a methodological individualism philosophy and "incorporate individual behavior and ... use theories of individual behavior » (Holm et al.). Population or employment evolution of a neighborhood as well as of a region or a city is obtained by aggregating individuals' positions. The results have shown to be satisfactory for testing the effects of planning scenarios at the scale of an employment area where chain mechanisms shape individuals' behavior when choosing for a job or a housing (a household moving out of its dwelling, creates for example an opportunity for new comers (Holm et al. 2000, Waddell 2002, Wegener 2011). However, at the scale of system of cities, more complex mechanisms are involved. In that respect, the choice made in EUROSIM (Sanders et al., 2007, Pumain et al., 2009), a simulation model of the European system of cities, was to formalize hypotheses at the level of "city-agents" and their interactions. The underlying hypothesis is that of a relative autonomy of the city rather than the «aggregate consequences of individual behavior". The model is developed with a multi-agent system where the agents are the cities which are characterized by their properties (size, economic specialization) and which interact (through an economic market). The spatial and hierarchical structure of the cities emerges from those interactions at the higher level of observation represented by the system of cities. The key element concerns the formalization of the interactions between the city-agents. Regarding states, Hay (2014) suggests:

"that the state is perhaps best seen as neither real nor fictitious, but 'as if real' - a conceptual abstraction, yet one to we which might still accord a very significant generative and causal power $»$.

This expression "as if real" corresponds to the choice made in the EUROSIM model to formalize interactions. The city-agents are neither of statistical type, neither representative of some urban actors. They are geographic constructs whose interactions operate " as if » each city was represented by a global city-actor. The model was able to explore the consequences of different economic constraints on interactions between European cities. 
Such approach makes particularly sense in a long term perspective. Indeed, it is because of the interweaving of a variety of components referring to different scales, in time and space, that the city can be considered as an indivisible entity. The material, cultural, socioeconomic dimensions have been built up and transmitted through dozens and even hundreds of generations of people whose main purpose was not to maintain or to make the city grow. Self-organization is then a central process which explains how a city is evolving in a system of cities.

\section{The question of "multiple realizabilty": from an empirical perspective}

Following the previous elements, another perspective can be undertaken to add more empirical elements to this cross-disciplinary discussion between economists and other scientists focused on cities and geographers. So it seems important to explore this difference in observation levels and their implications in terms of interpretation. For the geographers interested by system of cities, the contribution of the macro and meso levels scale is high and they are convinced that this approach brings new knowledge both about the evolution of the system and about the possibility to compare different kinds of systems, all around the world. It seems that many analyses about dynamics of urban systems led by economists characterize emergence from the micro level to the macro level while most of the researches in geography on urban systems take place in the articulation of the meso level and the macro level.

From a geographical point of view, the population size can be considered as a good summary of the effects of micro level mechanisms, both qualitative and quantitative, for studying links and relationships between meso and macro levels. Obviously, all cities evolve according to different growth rates. In all systems around the world, one observes a lot of variability, as well in United States, as in France or in emergent countries, or elsewhere. Individual city trajectories are diversified. But this observation is not in contradiction with the regularities that one can observe at the macro-geographical level of system of cities. Actually we start from the observation that the emergent properties at the meso or macro level can "forget" for the description all the "micro movement" that built them - not keeping the details. Butterflies and lions agree that a methodological mistake would be to believe that it would 
be necessary to study each small flow or change separately, each individual intention, in order to understand what happens at a higher level of observation.

So, it seems that different approaches of urban systems co-exist and they should be complementary in the debate between economists or other felines and geographers to go towards a hybrid way of exploration and thinking. The principle of methodological individualism is difficult to maintain if one is interested in developing an ability to understand the trajectories of the urban entities at a meso-level. This debate does not only affect the geography but it's more cross-disciplinary. Indeed, List and Spiekermann (2013) argue how this debate exists in political science and how a reconciliation is possible between the two perspectives, the individualist one (i.e the micro scale) and the holist one.

By analogy, as butterflies, we can question the conditions of a holist position facing the urban systems analysis. "A social system requires explanatory holism if and only if three jointly necessary and sufficient conditions are met: 1) Multiple levels of description: The system admits lower and higher levels of description, associated with different level-specific properties (e.g., individual-level properties versus aggregate-level properties); 2) Multiple realizability of higher-level properties: The system's higher-level properties are determined by its lower-level properties, but can be realized by numerous different configurations of them and hence cannot feasibly be redescribed in terms of lower-level properties; 3 ) Microrealization-robust causal relations: The causal relations in which some of the system's higher-level properties stand are robust to changes in their lower-level realization".

The first point has already been discussed above. The two following points, "multiple realizability" and "microrealization-robust causal relations", can be demonstrated by the fact that most of processes which lead the urban systems' dynamics (population settlement process or economic trajectories) are comparable in the world even if the processes at the micro-scale level, i.e the local level, are different and particular. On a way, this debate can also be related with the one about the opposition, about territorial dynamics, between singularity (or specificity) and universal (or general). The idea from F. Durand-Dastès (1991) ${ }^{2}$ expresses one main challenge to rise when we analyze a geographical space. Moreover,

\footnotetext{
${ }^{2}$ La question des rapports entre le particulier et le général n'est pas propre à la géographie, puisqu'elle se pose en fait dans toutes les disciplines.
} 
according to Hegel, the comparative approach is a relevant way of thinking the difference between singularity and universalism. "Nature shows us a countless number of individual forms and phenomena. Into this variety we feel a need of introducing unity : we compare, consequently, and try to find the universal of each single case". (Hegel, 1830).

So, let us take some empirical examples, in different countries, to illustrate these ideas. The analysis of various urban systems allows us to claim that different causalities, multiple urban morphogeneses, different initial situations, at the micro level, lead to the same results, to the same process at the macro level. An exploratory and comparative approach between different urban systems demonstrates that some properties are shared among the systems, at the macro level, produced by multiple interferences and by spatio-temporal crossbreeding of processes (Vacchiani-Marcuzzo, 2016). For example, the comparison between rank-size regularities among different countries, from the North or the South, reveals a strong similarity at this macro-geographic scale of urban systems.

Figure 1. Urban Rank-Size distributions in different countries (2010)

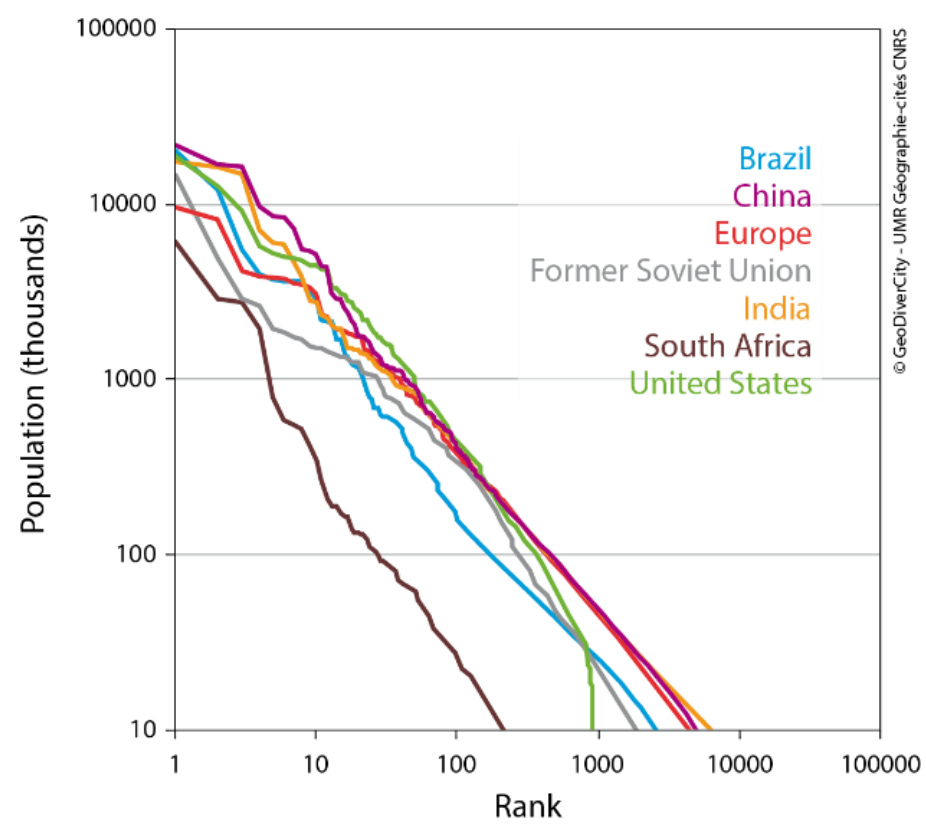

The differences among the urban systems about their emergence and their formation are real. Some of them are born from a long-standing process of urbanization (as Europe or India) and some are the results of a settlement colony (United States or South Africa). Then, the contexts are extremely different. Moreover, the agents' behaviors on an individual level also vary, in particular due to different weights of informal economic sector from one 
country to another, especially between emerging and developed countries. Nevertheless, despite of these differences, we observe in all countries relatively close urban dynamics (figure 2). The similarity of their evolution is remarkable and it illustrates the systemic trend of "self-reproduction" of the territories, whatever their localization.

We can pursue this empirical demonstration through the economic dynamics of urban systems. Indeed, this feature of dependence to the past is also present in evolutionary economic theories (Boschma and Martin, 2010; Boshma and Frenken, 2006) where the economic transformations observed at various regional levels (country, region, city, etc.) come partly from the impacts of small historical events that guide the dynamics of cities. All the urban systems were concerned by the succession of innovation cycles, with temporal gaps. And these cycles left strong footprints in the current structures of urban systems (Figure 3).

Figure 2. The economic diversity in three urban systems

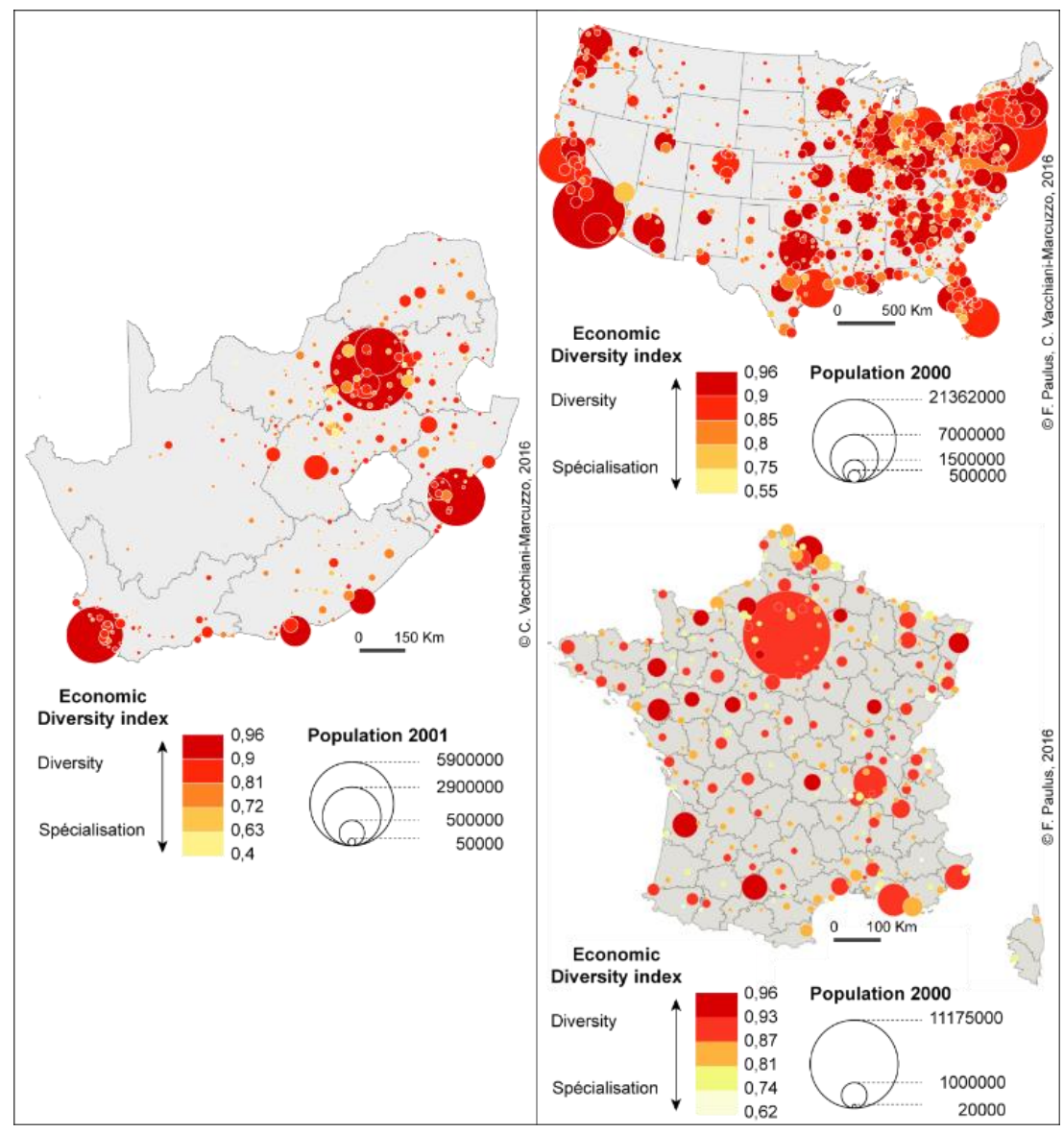


For example, the comparison between the structure of activities through three urban systems (South Africa, France and United States) is strongly similar at the beginning of the XXle century. The empirical and static analysis reveals a common high diversity and complexity of the activities portfolio for the biggest cities among the three systems. This parallel result at the level of urban system is coming from various situations at the more local scale, but they led to the same results. This empirical result is closed to the demonstration in political science advanced by List and Spiekermann (2013) about the multiple realizability and the fact that the properties observed at a higher level (in our case, the urban system level) can be the results of a multitude of different situations at the lower level (the level of each individual city inside the system).

Another empirical example can be the urban trajectory of different urban systems through the economic cycles of innovation. The comparison since the 1960's of the mean economic trajectory of three different urban systems (Figure 4) reveals a similar trajectory through the transition from an industrial society (The Old Economy) to a services industry society (The New Economy), main feature observed everywhere.

Figure 3. The economic trajectory of cities

(South Africa, Unites States, France) 

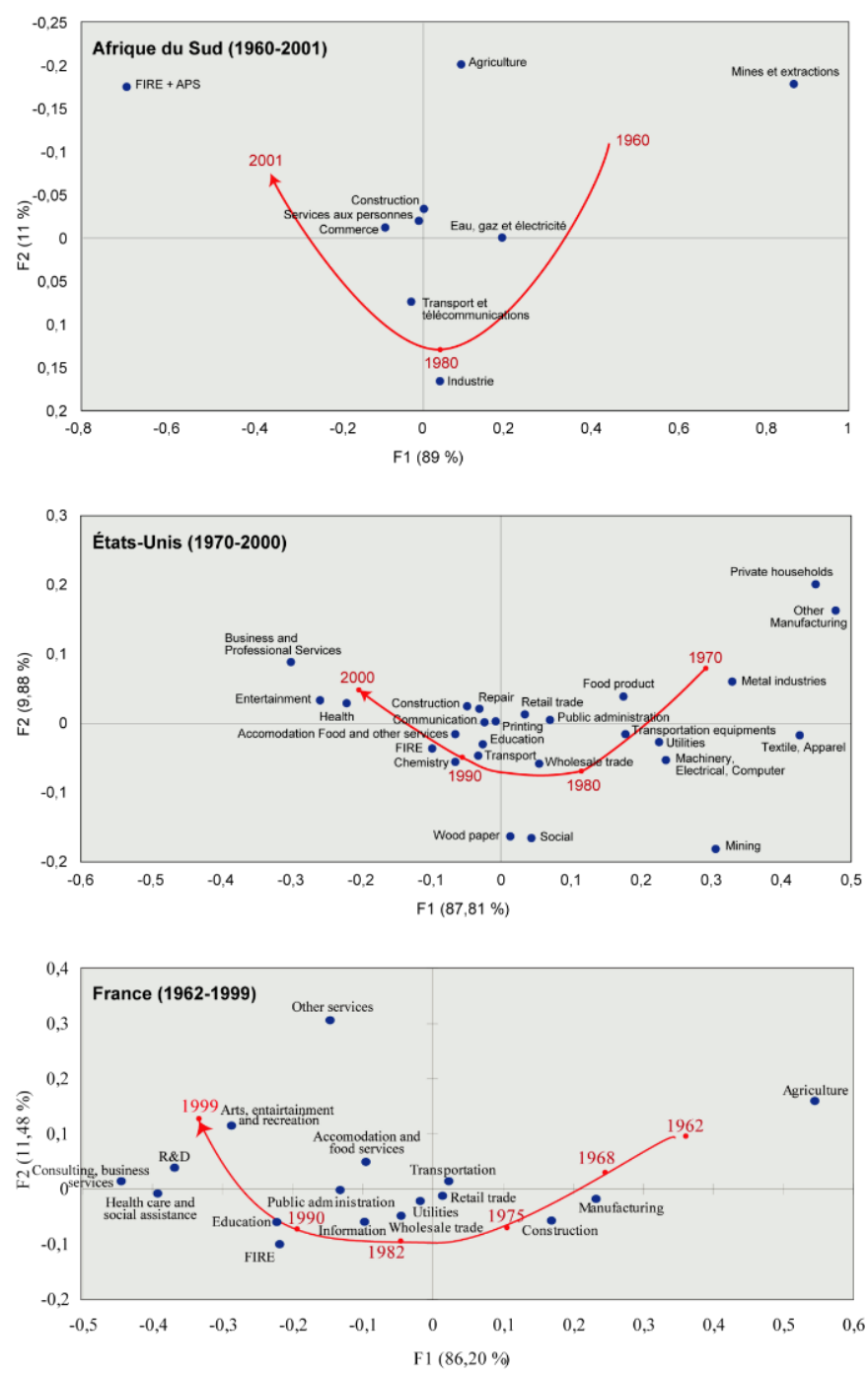

At the macro-scale, the economic profile reveals a shift or a bifurcation (earlier in the industrialized countries as France or USA in the 1970's, later in emergent countries as South Africa, in the 1980's) towards more skilled and more globalized urban functions (Finance, Insurance, Advanced Producer Services, Research and Development, Arts and Leisure, etc.). This shift, characteristic of the post-fordism economy, follows different rhythms among the urban systems but draws the same main trends, even though each individual city, inside the systems, can follow different trajectories.

Finally, both in the demographic and economic evolution of cities, there is a convergence of the processes at the macro scale of the urban system, whatever the different dynamics at the meso-scale ot the micro-scale. This empirical approach allows us to hence the difference in terms of scale in the debate between geographers and other felines. 


\section{Butterflies, lions and other felines.}

Let us now consider a lived research experience based on a participation to a EU project where researchers from several disciplines (including economists) aimed at applying the UrbanSim Land Use and Transport Interaction (LUTI) model to three European cities (Paris, Brussels and Zurich) (see Bierlaire et al., 2015). Jonathan Jones further developed this topic in his PhD dissertation and in the consequent scientific papers (see Jones et al 2015a and 2015b, 2017; Thomas et al., 2018); these publications will be the main source of inspiration of this section and have the advantage of opening the debate to other disciplines than economics. We knew from the very beginning of the research project that LUTI models were data intensive and hence often leading to data crunching rather than modelling; as expected, we drowned into data problems among which the delineation of the cities and the choice of the basic spatial units.

We know from urban geographers that comparing cities needs undoubtedly to control the delineation of the urban agglomerations. Indeed, a city is a dot on a map but only for location purposes at a very small scale (i.e. a world map), but at any larger scale a city is always characterized by an extent (surface), a morphology (shape), and also by living masses (inhabitants/households/firms) and these masses can change over time in size and composition. Consequently, each city has a different footprint determined by complex organization of its masses, but also by interacting actors and processes such as its geography, history or governance (e.g. Batty, 2005; Derycke et al., 1996; Abdel-Rahman and Anas, 2004; Parr, 2007; Tannier and Thomas, 2013). Despite EU efforts, there is no/very little international agreement about the delineation of functional urban regions and various cut-off values are often basically used (e.g. Cheshire and Gornostaeve, 2002; Dujardin et al., 2007; Thomas et al., 2012). Moreover, cities are interconnected, hierarchically organized (Pumain, 2006) and hence difficult to clearly isolate. Last but not least, it is rather difficult to delineate a city because its built-up surfaces dilute farther and farther away from the city center within rural areas, thus blurring the morphological and functional limits of the city (Caruso et al., 2007; 2011). This problem becomes even more complex when the polycentric nature of the urban systems is taken into consideration. Hence, the hinterland of a city cannot easily be isolated from another, and all these urban extensions are sources of complex and multifaceted mobility behaviors (e.g. Cervero, 2002; Handy et al., 2002). 
Though this is stating the obvious in urban geography literature and continuously and by the availability of new data types (crowd-sourced transport geo-spatial information, urban sensors, social network data scrawled on the Internet, land use change at cadastral level, etc.), it is much less so in other disciplines such as for instance economics and transport economics where we see that researchers and consultants have taken a very pragmatic view on urban delineations as well as the choice of basic spatial units: they often forget that their choice may hardly impact the modelling results. This was developed in Thomas et al (2018), a paper that constitutes the background of this section.

LUTI models are indeed derived from the classical four-step model. The first generation of models led to applications in the US such as MEPLAN (see Echenique et al., 1990) or TRANUS (see de la Barra, 1989) mainly due to federal regulations requiring land use impacts of new transport infrastructure to be assessed. Their spatial diffusion to Europe is more recent and scarce: LUTI models still appear nowadays to be mostly a pragmatic integration of bits of land use within transport models rather than the opposite, and therefore are weakly connected to urban land use, especially in the aspects related to urban dynamics (Anas, 2013). Thomas et al (2018) concentrated on the lack of attention paid to the definitions of cities when applying these models. Their argumentation develops on a systematic metaanalysis of 21 peer-reviewed publications about applications in European cities. Most papers are not written by butterflies sand most authors ignore geographical biases about city size and delineation as well as the grain (size and shape of the basic spatial units and hence the definition of the statistical individual). Thomas et al. (2018) also conducted simulations on a synthetic urban area consisting of 2 city centers (W and E) in a rectangular study area (see Figure 4); the size of the cities was later changed as well as the extend of the W city which is growing further and further right (Exx on the figure) up to capturing the right hand side city (E). Increasing Exx from left to right results in a progressive inclusion of the CBD of $E$ into the studied area.

Figure 4: The theoretical case study used for simulation 


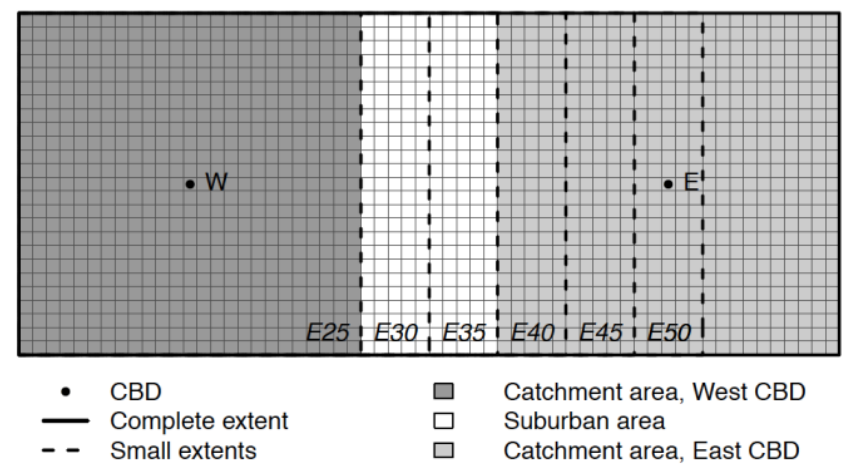

(Exx is the urban extents, $x x$ referring to the number of columns from the Western extremity; $W$ and $\mathrm{E}$ are two different $\mathrm{CBDs}$ )

Source : Thomas et al. (2018)

The simulations reported confirm that the absence of control on city delineation strongly weakens the LUTI result, impacting in particular commuting times. The delineation of the city area plays a major role as well as the size of the spatial units (Jones, 2015b and 2017) in transport modelling results and the consequences for not controlling these effects are clearly underestimated in the transport literature.

While practical concerns are perfectly understandable, there is a risk of undermining the effects of choosing the limits of an urban system, especially because models involve complex processes that are more and more detailed geographically and disaggregate in terms of agents, include many non-linear interactions and feedbacks across scales, and actually crunch large and heterogeneous data. Assessing the effect of system boundaries is important to provide certainty and robustness to model findings; this is also true in urban and transport research as soon as one intends to contribute generalizable scientific knowledge about the functioning of city regions. Ideally contributed knowledge should be independent from the dataset, and should also be easily transferable across case studies. Both require transparency in how the geographical limits are chosen and how this choice impacts the spatial distribution and variability of data and whether or not it affects results.

When selecting a city, the larger the study area, the largest the risk of including functional or morphological parts of other cities, especially in densely inhabited regions. Different delineations can therefore change the nature of the studied urban system and automatically determine important parameters of the model including transport outcomes as well as the level of system inertia/response to scenarios. This already was a point in Lee (1973)'s 
requiem on large-scale models, emphasizing wrongheadedness when implementing gravity processes at all scales. By bypassing the discussion on the size and extent of cities, transport modelers may actually have slowed down the integration in urban theory of their findings related to particular cases and geographies. After almost 50 years of LUTI applications, the theoretical and legitimate promises of a fully interacting land use and transport systems may then not have been fully met. While mature in practical terms, the field still seems to lack of capacity to contribute generalizable scientific knowledge about the functioning of city regions especially because of difficulties in case studies comparability and full transparency in application. On the other extreme, the standard urban economic literature, after Alonso, while informing clearly on generic policies and optimal instruments (cordon, taxes, etc. to tackle sprawl, congestion or negative externalities; e.g. Brueckner, 2001; De Borger et al., 2008) stays far from empirical validation beyond stylized facts, and real case calibration and implementation are rare. Hence, urban geographers and planners cannot easily capitalize on transport and land use models. This is somehow a rejoinder to Saujot et al. (2016) who emphasize a gap between theory and the end-users, although our viewpoint is rather that the outcome of LUTI implementations may not be sufficiently general and robust to transfer between cases with a different urban geographical reality.

We could stop here with the example of LUTI models (which are not mainstream economics) and their lack of realistic urban European applications, but (unfortunately) many other models suffer from the same problem. Surprisingly enough, despite early papers about urban modelling, scales and urban borders, this problem is still up to date and even revive nowadays with the invasion of unconventional (massive) data for which several biases are often pinpointed but where spatial aggregation (size and shape of basic spatial units; definition of studied area) is once again ignored or - worse - even re-invented (Kitchin, 2013; Miller and Goodchild, 2015; Miller, 2018). Geographers publish, their research is available on the web and in international geography journals, but it seems that the border between disciplines is hardly crossed. Are discipline jargons the only brake to dialogue? Is it so hard for lions or tigers to listen and understand butterflies?

Conclusion 
Facing urban phenomenon, all social sciences have something to say and are able to provide elements of understanding. Indeed they have complementary methodological savoir-faire. Economists' methods are very useful to formally show how rational individual behaviors produce spatial structures. On their side, data scientists offer stimulating tools to analyze informal massive data, even if, of course, we can't let the data speak by themselves. Geographers produce methods able to take astutely into account scale and space effects. Together they contribute to the building of knowledge about handling space, its complexity and its biases in modelling. Many scientific approaches are relevant and it's essential to combine different theoretical analyses. It is also very fertile to decline empirical process at different scales, according various delineations of the urban object. Indeed, each way of thinking corresponds to a point of view on the studied phenomenon. It is time that felines and butterflies exchange and co-evolve in the fascinating world of interdisciplinarity. 


\section{References}

ABDEL-RAHMAN HM., ANAS A. (2004) Theories of systems of cities. In Henderson JV., Thisse JF. Handbook of regional and urban economics. Volume 4 Cities and geography. North-Holland: Elsevier: 2293-2340.

ANAS A. (2013) A response to the guest editorial: economics as the science for urban modelling, Environment and planning B, 40: 955-958

BATTY M. (2005) Cities and complexity: Understanding Cities with cellular automata, agent-based models, and fractals. Cambridge (Massachusetts, USA): MIT Press.

BIERLAIRE M., A. DE PALMA, R. HURTUBIA and P. WADDELL (Eds.) (2015) Integrated Transport and Land Use Modeling for Sustainable Cities, EPFL Press / Routledge. 280 p.

Boschma R., Martin R. (eds), 2010, The handbook of Evolutionary Economic Geography, Cheltenham, Edward Elgar Publishing.

Boschma R., Frenken K., 2006, Why is economic geography not an evolutionary science? Towards an evolutionary economic geography, Journal of Economic Geography, vol. 6, 3, 273302.

BRUECKNER, J. K. (2001). Urban sprawl: Lessons from urban economics. Brookings-Wharton papers on urban affairs, 2001(1), 65-97

CARUSO G., VUIDEL G., CAVAILHÈS J., FRANKHAUSER P., PEETERS D., THOMAS I. (2011) Morphological similarities between DBM and a microeconomic model of sprawl, Journal of Geographical Systems 13(1), pp. 31-48.

CARUSO, G., PEETERS, D., CAVAILHÈS, J., ROUNSEVELL, M. (2007) Spatial configurations in a periurban city. A cellular automata based micro economic model, Regional Science and Urban Economics, 37, 542-567

Caterina Marchionni and Petri Ylikoski, 2013, Generative Explanation and Individualism in AgentBased Simulation, Philosophy of the Social Sciences, 43(3) 323-340

CERVERO, R. (2002) Built environments and mode choice: towards a normative framework, Transportation Research Part D, 7(4), 265-284

CHESHIRE, PC. GORNOSTAEVE, G. (2002) Villes et régions urbaines: des comparaisons fiables doivent reposer sur des territories comparables, Les Cahiers de l'IAURIF, 135, 13-32

DE BORGER, B., PROOST, S., \& VAN DENDER, K. (2008) Private port pricing and public investment in port and hinterland capacity. Journal of Transport Economics and Policy (JTEP), 42(3), 527-561

DE LA BARRA T. (1989) Integrated land use and transport modelling. Cambridge: Cambridge University Press.

DERYCKE P.H. HURIOT J.M. PUMAIN D. (1996, eds) Penser la ville. Théorie et modèles. Paris: Anthropos.

DUJARDIN C, THOMAS I, TULKENS H (2007) Quelles frontières pour Bruxelles? Une mise à jour. Reflets et perspectives de la vie économique 46(2-3),:155-176

Durand-Dastès F., 1991, Le particulier et le général en géographie, in F. Audigier et G. Baillat (eds.), Actes du $6^{\circ}$ colloque de Didactiques de l'histoire de la géographie, des sciences sociales, 1991, 207216.

ECHENIQUE, M., FLOWERDEW, A., HUNT, J., MAYO, T., SKIDMORE, I., SIMMONDS, D. (1990) The Meplan model of Bilbao, Leeds and Dortmund, Transport Reviews 10(4), 309-322.

GABAIX, Xavier (1999) Zipf's Law and the Growth of Cities. American Economic Review, vol. 89, no 2, p. 129-132. 
HANDY, S. L., BOARNET, M. G., EWING, R., \& KILLINGSWORTH, R. E. (2002) How the built environment affects physical activity: views from urban planning. American journal of preventive medicine, 23(2), 64-73

Hay, C.S. (2014) Neither real nor fictitious but 'as if real': A political ontology of the state", British Journal of Sociology, 65 (3). pp. 459-480.

Hegel, 1830, Encyclopaedia of the philosophical sciences, Logic, Clarendon Press (1975)

HENDERSON, J. Vernon (1974) The sizes and types of cities. The American Economic Review, p. 640656.

Hodgson G. M., 2007 VERIF, Meanings of Methodological Individualism, Journal of Economic Methodology, 14(2), June, pp. 211-26.

Holm E, Lindgren U, Kirsten Holme, Mäkilä K., 2002, The SVERIGE Spatial Microsimulation Model

JONES J., PEETERS D., THOMAS I. (2015a) Is cities delineation a pre requisite for urban modelling? The example of land price determinants in Brussels, Cybergeo Article 716

JONES J., PEETERS D., THOMAS I. (2017) Scale effect in a LUTI model of Brussels: challenges for policy evaluation. European Journal of Transport and Infrastructure Research (EJTIR), 17(1), 103-131

JONES J., THOMAS I., PEETERS D. (2015b) Forecasting employment location choices by Discrete Choice Models: A sensitivity analysis to scale and implications for LUTI models. REGION 2(1): 67-93.

KITCHIN, R. (2013) Big data and human geography: Opportunities, challenges and risks. Dialogues Hum. Geogr. 3, 262-267.

Krugmam P., 1996, Confronting the Mystery of Urban Hierarchy, Journal of the Japanese and international Economies, 10, 399-418.

LEE JR, D. B. (1973). Requiem for large-scale models. Journal of the American Institute of Planners, 39(3), 163-178.

List C., Spiekermann, 2013, Methodological individualism and holism in political science: a reconciliation, American Political Science Review, 107, 4, 629-643.

MILLER H. (2018), Geographic information science II : Mesogeography : Social physics, GIScience and the quest for geographic knowledege, Progress in Human Geography, 42(4), 600-609

MILLER H., GOODCHILD M. (2015), Data-driven geography, GeoJournal 80 :4, 449-461

PARR JB. (2007) Spatial definition of the city: four perspectives, Urban Studies, 44(2), pp. 381-392

Peter Hedström and Petri Ylikoski, 2010, Causal Mechanisms in the Social Sciences, Annual Review of Sociology, 36:49-67

PUMAIN D. (2006, ed) Hierarchy in natural and social sciences. Dordrecht (NL): Springer.

Pumain D., Sanders L., Bretagnolle A., Glisse B., Mathian H., 2009, The future of urban systems: exploratory models in Lane, van der Leeuw, West, Pumain (eds), Complexity perspectives on innovation and social change, Springer, Methodos series, p331-359.

Sanders L., Favaro J.-M., Mathian H., Pumain D., Glisse B., 2007, "Intelligence artificielle et agents collectifs : le modèle EUROSIM ", Cybergeo : European Journal of Geography [En ligne], Dossiers, document 392.

SAUJOT, M., DE LAPPARENT, M., ARNAUD, E., \& PRADOS, E. (2016). Making land use-Transport models operational tools for planning: From a top-down to an end-user approach. Transport Policy, 49, 20-29.

Sawyer, R. K. 2002. 'Nonreductive Individualism. Part I - Supervenience and Wild Disjunction.' Philosophy of the Social Sciences 32 (4): 537-559.

SIMON, Herbert A. (1955) On a class of skew distribution functions. Biometrika, vol. 42, no 3/4, p. 425-440. 
Smith B., Varzi A.C., 2000, Fiat and bona fide boundaries, Philosophy and Phenomenological Research, vol. 60, 2, p401-420.

Storper M., 2017, Urban systems: the geography of income and population (PPT), Colloquium ERC, Theories and Models of Urbanization (Paris, 13 October 2017)

TANNIER C., THOMAS I. (2013) Defining and characterizing urban boundaries: A fractal analysis of theoretical and real Belgian cities, Computers, Environment and Urban Systems 41, 234-248

THOMAS I., COTTEELS C., JONES J, PEETERS D. (2012) Revisiting the extension of the Brussels urban agglomeration: new methods, new data ... new results? E-Belgeo (on-line), URL: http://belgeo.revues.org/6074

THOMAS I., JONES J., CARUSO G., GERBER P. (2018) City delineation in LUTI models: review and tests, Transportation Reviews, 38(1), 6-32.

Udehn, L. 2002. The Changing Face of Methodological Individualism, Annual Review of Sociology 28: 479-507.

Vacchiani-Marcuzzo C., 2016, Is the South African urban system apart? Assessment of an Urban Hybridity, Habilitation à diriger des recherches, Université de Paris 1- Panthéon-Sorbonne.

Waddell, Paul, 2002, "UrbanSim: Modeling Urban Development for Land Use, Transportation and Environmental Planning", Journal of the American Planning Association, vol. 68, n. 3, p.297-314.

Wagner, Peter et Michael Wegener, 2007, "Urban Land Use, Transport and Environment Models; Experiences with an Integrated Microscopic Approach", disP 170, 3, p.45-56.

Wegener M., 2011, From macro to micro-how much micro is too much?, Transport Reviews, Taylor \& Francis

Ylikoski P., 2014, Rethinking Micro-Macro Relations, in J. Zahle, F. Collin (eds) Rethinking the Individualism-Holism Debate, Essays in the Philosophy of Social Science, Springer, 117-135. 